\title{
Development of a tropoelastin-binding MR contrast agent for in vivo imaging of impaired elastogenesis in atherosclerosis
}

\author{
Alkystis Phinikaridou ${ }^{1 *}$, Sara Lacerda ${ }^{1}$, Marcelo E Andia ${ }^{2,1}$, Rene Botnar ${ }^{1}$ \\ From 18th Annual SCMR Scientific Sessions \\ Nice, France. 4-7 February 2015
}

\section{Background}

Elastin is a primary component of the vessel wall and present in all elastic vessels such as the aorta and the pulmonary artery. Elastogenesis begins with the synthesis and secretion of the soluble precursor tropoelastin that becomes cross-linked into insoluble elastin. Under normal conditions cross-linked elastin is the only form of the molecule present in the vessel wall whereas tropoelastin is absent. Conversely, under pathological conditions including atherosclerosis and aortic aneurysms elastogenesis resumes and tropoelastin molecules accumulate in the vessel wall. We developed a novel tropoelastin-binding MRI contrast-agent that would allow 1 ) specifically bind to tropoelastin but not to cross-linked mature elastin to allow 2) detection of pathologic elastogenesis that occurs in atherosclerosis and 3) minimizing non-specific signal from endogenously present mature elastin.

\section{Methods}

Two tropoelastin-binding peptides (Gd-DOTA)VVGSPSAQDEASPLS and K(Gd-DOTA)YPDHVQYTHY were tested. In vitro binding studies were performed using Europium-labeled peptides and a DELFIA method. In vivo MRI of the aortic and brachiocephalic arteries was performed in atherosclerotic $\mathrm{ApoE}^{-1-}$ and control mice using a 3T Philips Achieva scanner and a single loop microscopy surface coil. Images were acquired for up to $1 \mathrm{~h}$ after intravenous administration of $0.2 \mathrm{mmol} /$ $\mathrm{kg}$ tropoelastin-binding probes. 3D gradient-echo DE-MRI images were acquired with FOV $=30 \times 8 \times 30 \mathrm{~mm}$, matrix $=300$, resolution $=0.1 \times 0.1 \mathrm{~mm}$, slice thickness $=0.25 \mathrm{~mm}, \mathrm{TR} / \mathrm{TE}=27 / 8 \mathrm{~ms}$, TR between subsequent

'Biomedical Egineering, King's College London, London, UK

Full list of author information is available at the end of the article
IR pulses $=1000 \mathrm{~ms}$, and flip angle $=30^{\circ}$. T1 mapping was performed using a 3D modified Lock-Locker sequence FOV $=22 \times 8 \times 36$, matrix $=180 \times 171$, resolution $=0.2 \times 0.2$, slice thickness $=0.5 \mathrm{~mm}, \mathrm{TR} / \mathrm{TE}=9.2 / 4.7 \mathrm{~ms}$, flip angle $=10^{\circ}$. T1 values were computed on a pixel-by-pixel basis using an in-house Matlab algorithm.

\section{Results}

In vitro binding assays showed high selectivity of the compounds towards tropoelastin compared to other proteins and particularly mature elastin (Fig 1). The VVGS probe achieved best discrimination between tropoelastin and mature elastin. Similarly, DE-MRI in vivo images showed enhancement of the diseased vessel wall (Fig. 2C-D, G-H; arrows), where tropoelastin is present, and less or no uptake in control animals (Fig. 2A-2B, $\mathrm{E}-\mathrm{F})$ where tropoelastin is absent. Quantitative analysis

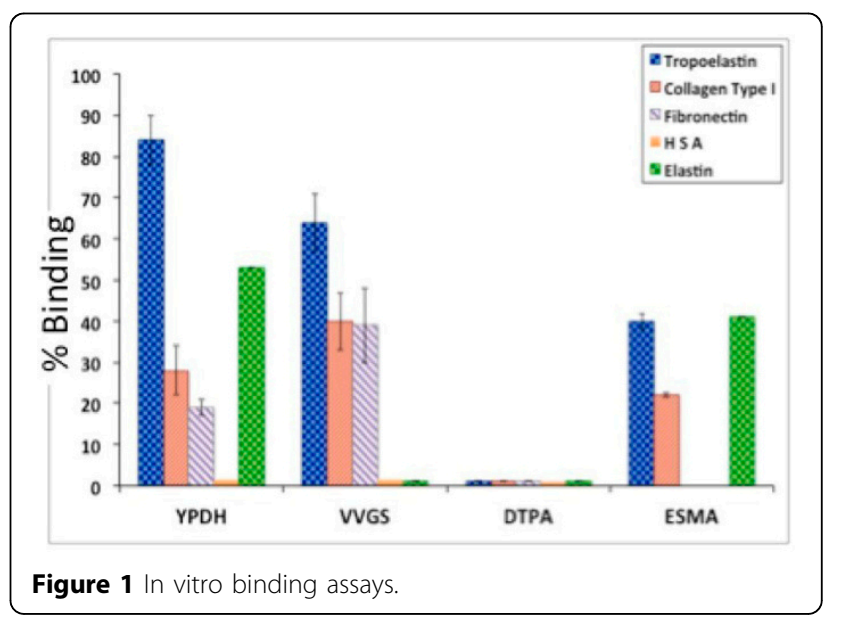



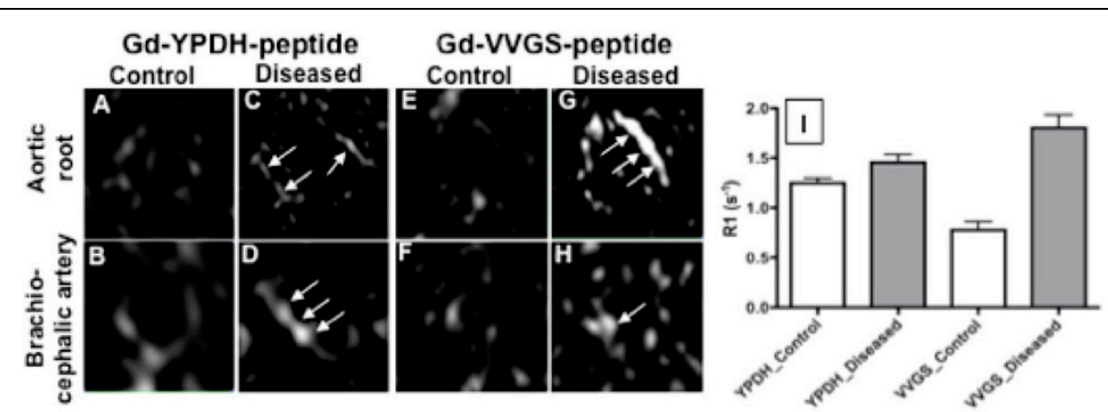

Figure 2 In vivo MRI experiments using the YPDH and WGS peptides in control and atherosclerotic mice.

of the vessel wall R1 showed a greater difference in R1 between control and disease vessels walls using the VVGS based probe (Fig. 2I).

\section{Conclusions}

We developed of a new gadolinium-based tropoelastinbinding contrast agent for imaging atherosclerosis. Both peptide-based probes showed promising pharmacokinetics, specificity and sensitivity for in vivo MRI imaging diseased brachiocephalic arteries in $\mathrm{ApoE}^{-/-}$mice. Further development of such contrast agent may allow for molecular imaging of impaired elastogenesis that accompany atherosclerotic plaque development and plaque vulnerability.

\section{Funding}

British Heart Foundation (RG/12/1/29262).

\section{Authors' details}

'Biomedical Egineering, King's College London, London, UK. 'Radiology, Pontificia Universidad Católica de Chile, Santiago, Chile.

Published: 3 February 2015

doi:10.1186/1532-429X-17-S1-0102

Cite this article as: Phinikaridou et al:: Development of a tropoelastinbinding MR contrast agent for in vivo imaging of impaired elastogenesis in atherosclerosis. Journal of Cardiovascular Magnetic

Resonance 2015 17(Suppl 1):0102.
Submit your next manuscript to BioMed Central and take full advantage of:

- Convenient online submission

- Thorough peer review

- No space constraints or color figure charges

- Immediate publication on acceptance

- Inclusion in PubMed, CAS, Scopus and Google Scholar

- Research which is freely available for redistribution

Submit your manuscript at www.biomedcentral.com/submit
Biomed Central 